\title{
Evaluation of antimicrobial activities of powdered cuttlebone against Klebsiella oxytoca, Staphylococcus aureus, and Aspergillus flavus
}

\author{
Ghazal Yazdanpanah $^{1}{ }^{\circledR}$, Neda Javid $^{1,2}{ }^{\circledR}$, Zhila Honarmandrad $^{3}$, Najmeh Amirmahani ${ }^{1}{ }^{\circledR}$ Alireza Nasiri $^{1^{+}}$ \\ ${ }^{1}$ Environmental Health Engineering Research Center, Kerman University of Medical Sciences, Kerman, Iran \\ ${ }^{2}$ Department of Environmental Health, Zarand School of Nursing, Kerman University of Medical Sciences, Kerman, Iran \\ ${ }^{3}$ Department of Process Engineering and Chemical Technology, Faculty of Chemistry, Gdansk University of Technology, 80-233 \\ Gdańsk, 11/12 Narutowicza Str, Poland
}

\begin{abstract}
Background: The presence of medicines in the environment is considered as a serious threat to the human health. The entrance of these substances into the water sources causes soil pollution, which eventually leads to the environmental pollution and it creates some problems for the public health. Also, increasing antibiotic resistant bacteria has attracted the attention of researchers to the use of natural resources such as marine products, for producing new antibiotics. The aim of this study was to evaluate antimicrobial activities of powdered cuttlebone against Klebsiella oxytoca, Staphylococcus aureus, and Aspergillus flavus.

Methods: At first, cuttlebones were washed, dried, and powdered. Then, the powdered cuttlebone was characterized. In the next step, its antimicrobial activities were evaluated using agar well diffusion technique, and minimum inhibitory concentration (MIC) was calculated.

Results: The powdered cuttlebone was found to be effective against $K$. oxytoca ( $24 \mathrm{~mm}$, MIC: $10^{-1}$ $\mathrm{mg} / \mathrm{mL}$ ), but no antimicrobial response was found against $S$. aureus. Also, the powdered cuttlebone antifungal activity and MIC against $A$. flavus were recorded $23 \mathrm{~mm}$ and $10^{-1} \mathrm{mg} / \mathrm{mL}$, respectively.

Conclusion: The obtained results suggest antimicrobial activities of powdered cuttlebone, which are concentration dependent. Furthermore, cuttlebone can be used as an accessible natural source to provide novel, low cost, and safe antimicrobial agents.

Keywords: Antibacterial activity, Antibiotics, Antifungal activity, Marine products, Minimum inhibitory concentration

Citation: Yazdanpanah G, Javid N, Honarmandrad Z, Amirmahani N, Nasiri A. Evaluation of antimicrobial activities of powdered cuttlebone against Klebsiella oxytoca, Staphylococcus aureus, and Aspergillus flavus. Environmental Health Engineering and Management Journal 2021; 8(1): 39-45. doi: 10.34172/EHEM.2021.06.
\end{abstract}

\section{Article History:}

Received: 10 November 2020

Accepted: 30 January 2021

ePublished: 3 March 2021

\section{Introduction}

Staphylococcus aureus is a gram positive and roundshaped bacterium, which is a member of Firmicutes species. S. aureus is the leading cause of human infections, which have a wide range in the environment and food sources. It can be transferred through food contact surfaces, hands, air, dust, etc. It typically causes skin infections, pneumonia, endocarditis, and osteomyelitis (1). Klebsiella oxytoca is one of several Klebsiella bacteria. Klebsiella spp. are ever-present in the environment. They could isolate from the soils, plants, and water surfaces. These bacteria are naturally found in the intestinal tract, mouth, and nose. Klebsiella spp. are opportunistic gramnegative, non-motile, and rod-shaped bacteria with a prominent polysaccharide capsule which belong to the
Enterobacteriaceae family. K. oxytoca is considered as an opportunistic pathogen and is recognized as a clinically significant nosocomial infection in children and neonates (2).

Aspergillus flavus is an opportunistic pathogen in immunosuppressed patients, which is found in the soils and causes diseases in the agricultural products. $A$. flavus is the major producer of aflatoxin. Aflatoxins are the second strong poisonous metabolites, which infect agricultural products and make serious threat to both humans and livestock health (3).

Due to the effects of pathogenic bacteria and toxinproducing fungi on the human health, it seems necessary to control them. The growth of dangerous bacteria and fungi is usually limited using chemical and synthetic 
preservatives. These materials have some side effects such as teratogenic and carcinogenic effects. The mentioned issues make concerns for the health officials. Today, because of the outbreak of new infectious diseases and antibiotic-resistant bacteria, it is necessary to use novel antimicrobial compounds with various chemical formations which have new action mechanisms. These reasons have forced researchers to look for new antibiotics from various renewable natural sources such as marine origin materials (4,5), citrus extract (6), natural oils (7), medicinal herbs like ginger (8), garlic (9), etc.

The antimicrobial activities studies supply valuable information about antibiotic discoveries, and also, provide a new insight into the extraction of bioactive compounds from natural sources (10). One of the natural resources that is considered these days is Mollusca marine animals. Cuttlefish is one of the Mollusca marine animals that belongs to the class Cephalopoda and order Sepioidea (11).

Recent studies have shown that cuttlefish is among the most intelligent species of invertebrates. They are nocturnal and hunt crabs and shrimps in the night. Cuttlefish have a unique internal shell, which is called cuttlebone and exists in all members of Sepiidae family. In the native dialect, it is called seabed (Figures $1 \mathrm{a}$ and $\mathrm{b}$ ).

Cuttlebone is a hard brittle internal structure with high porosity in the back of the cuttlefish body, which is oval shaped and spongy. In fact, cuttlebone is a porous internal

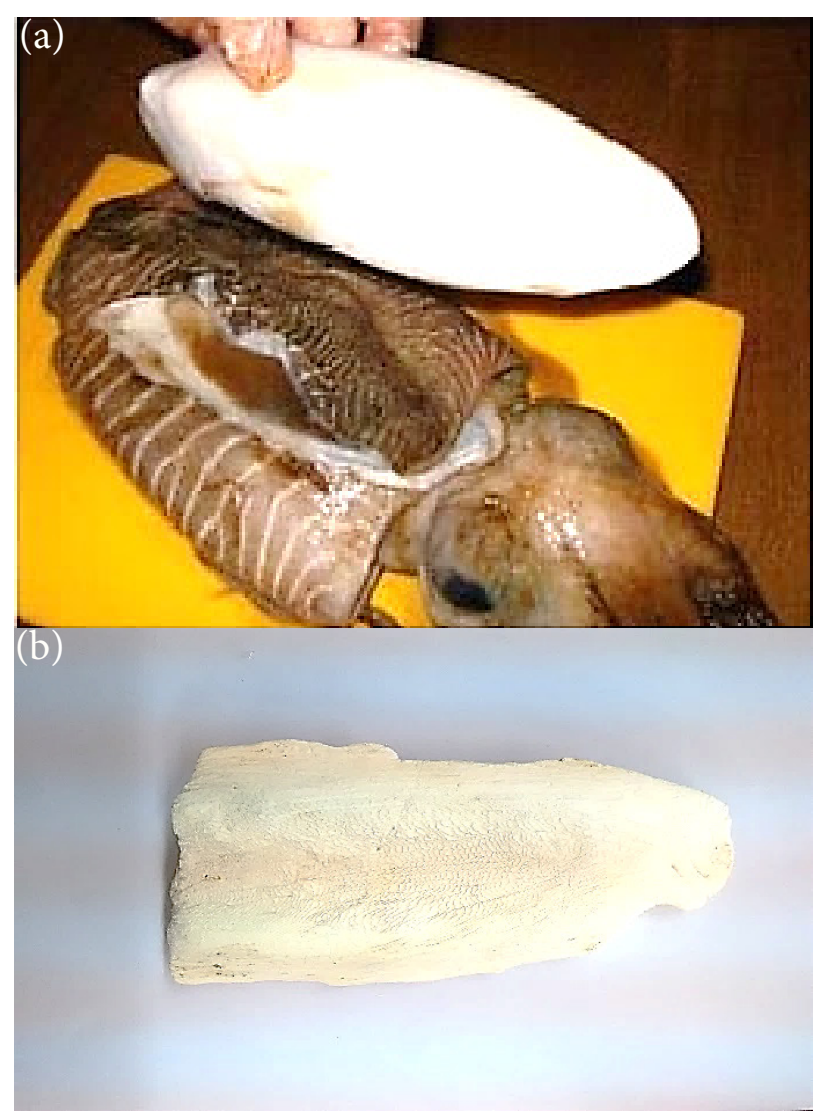

Figure 1. Cuttlebone isolated from cuttlefish (a), cuttlebone (b). shell that is made primarily of aragonite. It is a rigid buoyancy tank and functionally similar to swim bladder in fishes. It plays a key role in the protection of vital organs. Cuttlebone is made up of two parts: Organic part (protein and $\beta$-chitin) and inorganic part (calcium phosphate, sodium, magnesium, phosphorus, and mineral salts). Actually, cuttlebone is a marine product that contains no toxins or contaminants (12-16).

Due to the unique structure, cuttlebone has many pharmaceutical and industrial applications. It can be applied in the treatment of bleeding and control of external infections. Also, it can be used as a low-cost and nontoxic adsorbent in dyes, toxic elements, and removal of heavy metals from water and wastewater $(17,18)$. Its other applications include adjusting the bird's liver and kidney function, oil spill clean-up, healing of indomethacininduced acute gastric mucosal lesions in rats, biodiesel production, nanobiocomposite synthesis, preparing bone grafts, as an antioxidant, etc $(15,18-30)$.

It is noteworthy that previous studies have shown antibacterial and antifungal activities of polysaccharides and chitosan extracted from the cuttlebone.

According to the literature, antimicrobial activities of powdered cuttlebone have not been evaluated yet. In addition, because of several reasons such as easy availability, affordability, and naturalness of the cuttlebone, the present study was conducted to evaluate the antimicrobial activities of powdered cuttlebone against K. oxytoca, $S$. aureus, and A. flavus.

\section{Materials and Methods}

\section{Preparation of cuttlebone powder}

For this purpose, cuttlebones were collected from Bandar Lengeh county, Hormozgan, then, were washed by distilled water, and dried. After drying, the cuttlebones were powdered using an electric mill A320R1 (Moulinex, France). Then, the obtained powder was sterilized in an autoclave (Reyhan Teb, Iran) at $121^{\circ} \mathrm{C}$ for 15 minutes. Afterwards, the powder was characterized using a WQF510 FT-IR spectrometer (Bio-Equip, China). Also, the morphology and chemical composition of the powdered cuttlebone were investigated by the field emission scanning electron microscope (FESEM) and EDS-mapping (MIRA3 TESCAN XMU).

In the next step, to prepare the concentrations of serial dilutions of cuttlebone in a range of $10^{-1}-10^{-4} \mathrm{mg} / \mathrm{mL}, 1$ $\mathrm{mg}$ of the powdered cuttlebone was added to $10 \mathrm{~mL}$ of the ringer's solution (Merck, Germany) and was sonicated for 30 minutes.

\section{Microbial culture}

Lyophilized K. oxytoca PTCC 1402, S. aureus PTCC 1112, and A. flavus PTCC 5006 strains were purchased from Persian type culture collection (PTCC).

First, Mueller-Hinton agar (MHA) and Potato Dextrose 
agar (PDA) (Merck, Germany) were prepared and sterilized. Then, they were poured into the sterile plates.

The lyophilized bacterial and fungal were revived. Then, the 24 hour-old cultures of K. oxytoca and S. aureus, and 72 hour-old fungal culture of $A$. flavus were inoculated to the MHA and PDA media cultures, respectively, using a sterile swab. In addition, the standard antibiotic tetracycline and amphotericin B were used as negative controls. Also, $S$. aureus, K. oxytoca, and A. flavus suspensions were used as positive controls.

\section{Antibacterial and antifungal activities survey}

$0.1 \mathrm{~mL}$ of cuttlebone with different concentrations $\left(10^{-1}\right.$ $10^{-4} \mathrm{mg} / \mathrm{mL}$ ) was transferred by a sterile pipette into the wells ( $6 \mathrm{~mm}$ diameter). The wells were created on the agar media using a sterile cork borer. The plates were incubated at $37^{\circ} \mathrm{C}$ for 24 and 72 hours, respectively.

The antibacterial and antifungal activities of cuttlebone were investigated by agar well diffusion technique (31). To determine the minimum inhibitory concentration (MIC), the microbial cultures were checked for the presence or absence of growth zone around the wells and the growth inhibition halos were measured using a ruler. The experiments were repeated three times to prevent any errors in the results.

\section{Results}

\section{Cuttlebone characterization}

The FT-IR spectrum of cuttlebone at $400-4000 \mathrm{~cm}^{-1}$ is demonstrated in Figure 2.

To investigate the morphology and chemical composition of the cuttlebone, the FESEM image and elemental mapping were evaluated (Figure 3 ).

\section{Antimicrobial activities}

The powdered cuttlebone showed a good antibacterial activity against $K$. oxytoca (Table 1). However, no antibacterial response was observed against $S$. aureus (Figure 4a) at all concentrations. On the other hand, $S$. aureus was resistant against the powdered cuttlebone. It indicates that antibacterial activity was dependent on

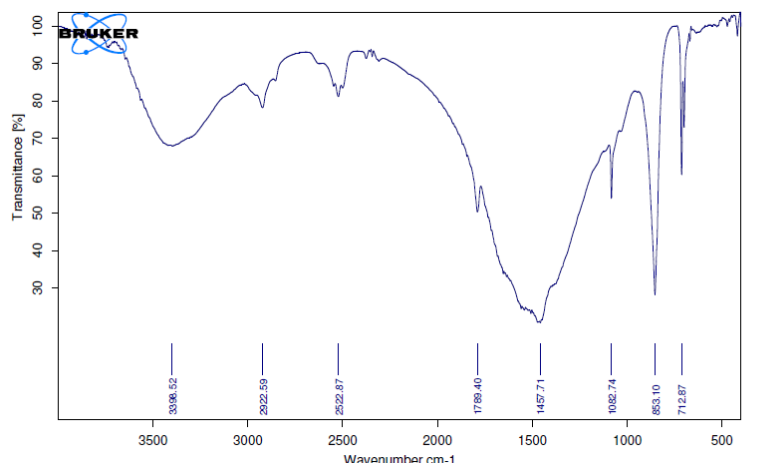

Figure 2. The FT-IR spectrum of cuttlebone.
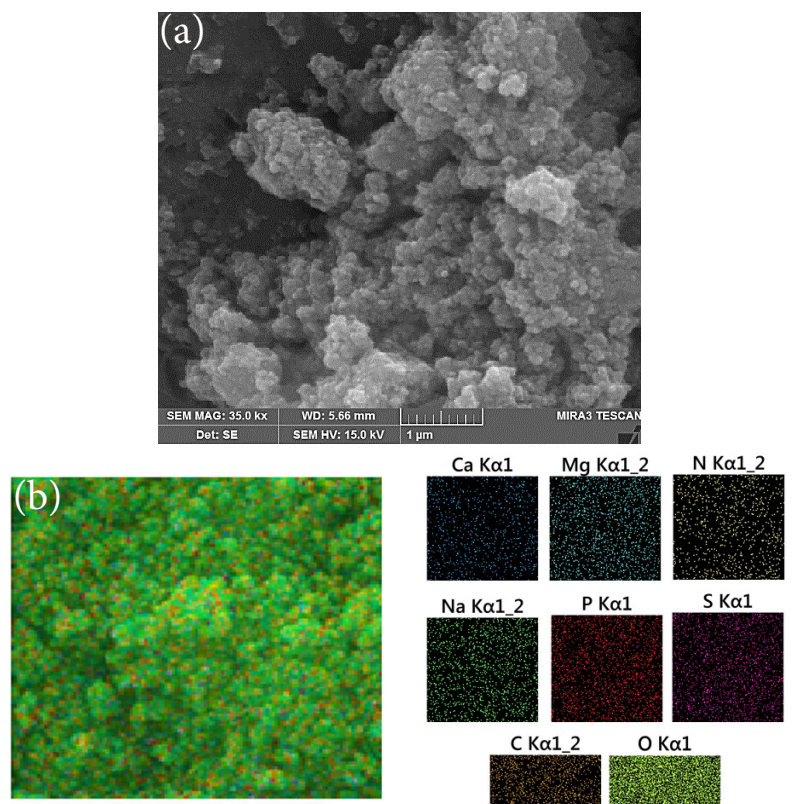

Ca 0 이 $\mathrm{N} S \mathrm{Sg}$ Na $\mathrm{P}$ Electron

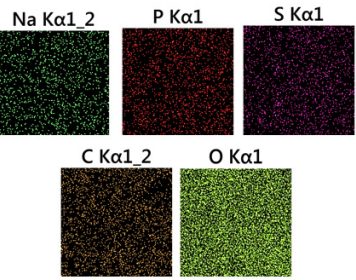

Figure 3. The FESEM image (a) and elemental mapping (b) of the cuttlebone.
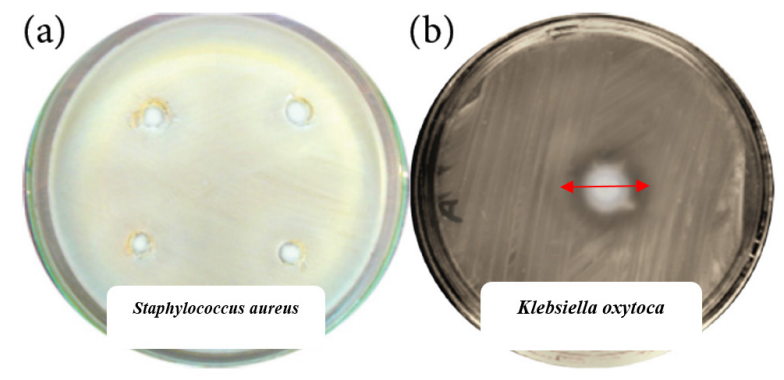

Figure 4. Cuttlebone antibacterial activity against $\mathrm{S}$. aureus (a) and $K$. oxytocic (b).

the cuttlebone concentration. In the negative control samples, no activity was observed. The highest and lowest inhibition zones against $K$. oxytocic were observed to be 24 and $11 \mathrm{~mm}$, respectively (Figure $4 \mathrm{~b}$ ).

\section{Antifungal activity}

The results shown in Table 1 summarize antifungal activity of cuttlebone. In the negative control samples, no antifungal activity was observed against $A$. flavus. The highest and lowest inhibition zones against $A$. flavus were observed to be 23 and $9 \mathrm{~mm}$, respectively. In addition, Figure 5 shows the highest inhibition zone against $A$. flavus.

\section{Minimum inhibitory concentration}

Table 2 shows the MIC values of powdered cuttlebone against $K$. oxytoca and A. flavus. The measured inhibition zones were compared with the negative controls and no activity was recorded for all pathogens. The highest and 
Table 1. Antibacterial and antifungal activities of powdered cuttlebone

\begin{tabular}{|c|c|c|c|c|c|c|}
\hline \multirow[b]{2}{*}{ Strains } & \multicolumn{4}{|c|}{ Inhibition Zone (mm) } & \multirow[b]{2}{*}{ Negative Control } & \multirow[b]{2}{*}{ Positive Control } \\
\hline & $\begin{array}{c}10^{-1} \\
(\mathrm{mg} / \mathrm{mL})\end{array}$ & $\begin{array}{c}10^{-2} \\
(\mathrm{mg} / \mathrm{mL})\end{array}$ & $\begin{array}{c}10^{-3} \\
(\mathrm{mg} / \mathrm{mL})\end{array}$ & $\begin{array}{c}10^{-4} \\
(\mathrm{mg} / \mathrm{mL})\end{array}$ & & \\
\hline S. aureus & - & - & - & - & - & $39 \pm 0.2$ \\
\hline K. oxytoca & $24 \pm 0.2$ & $12 \pm 0.1$ & - & - & - & $46 \pm 0.2$ \\
\hline A. flavus & $23 \pm 0.1$ & $13 \pm 0.2$ & $9 \pm 0.1$ & _ & _ & $43 \pm 0.2$ \\
\hline
\end{tabular}

Note. Values are presented as mean inhibition zone $(\mathrm{mm}) \pm \mathrm{SD}$ of three replicates.

Table 2. Cuttlebone MIC value against Klebsiella oxytoca, and Aspergillus flavus

\begin{tabular}{lcccc}
\hline \multirow{2}{*}{ Strains } & \multicolumn{4}{c}{ Powdered Cuttlebone $(\mathrm{mg} / \mathrm{mL})$} \\
\cline { 2 - 5 } & $10^{-1}$ & $10^{-2}$ & $10^{-3}$ & $10^{-4}$ \\
\hline S. aureus & +++ & +++ & +++ & +++ \\
\hline K. oxytoca & $*$ & + & +++ & +++ \\
\hline A. flavus & $*$ & + & ++ & +++
\end{tabular}

${ }^{*} \mathrm{MIC}$ concentration, +Slight growth, ++Medium growth, +++Strong growth.

lowest inhibition zones were obtained to be $10^{-2}$ and $10^{-3}$ $\mathrm{mg} / \mathrm{mL}$ against $K$. oxytoca and $A$. flavus, respectively.

\section{Discussion}

Regarding the chemical structure of cuttlebone, as shown in Figure 2, wide absorption band is observed at 3398 $\mathrm{cm}^{-1}$, that can be related to $\mathrm{O}-\mathrm{H}$ stretching vibrations on the adsorbent surface. The presence of the absorption bands at 2922 and $2522 \mathrm{~cm}^{-1}$ is because of the alkyl groups $(\mathrm{C}-\mathrm{H})$ and amine groups $(\mathrm{N}-\mathrm{H})$ in the cuttlebone structure, respectively. The absorption bands at $1457 \mathrm{~cm}^{-1}$ can be related to pyranose ring bending vibrations. Also, the absorption bands at 1082, 853, and $712 \mathrm{~cm}^{-1}$ can be attributed to $\mathrm{C}-\mathrm{O}, \mathrm{C}-\mathrm{H}$, and $\mathrm{C}-\mathrm{H}_{2}$ stretching vibrations, respectively. According to the results of FESEM image and elemental mapping, the presence of $\mathrm{Ca}, \mathrm{Mg}, \mathrm{N}, \mathrm{Na}$, $\mathrm{P}, \mathrm{S}, \mathrm{C}$, and $\mathrm{O}$ in the chemical structure of cuttlebone was confirmed (Figure 3).

The main aim of the present study was to evaluate antimicrobial activities of powdered cuttlebone against $K$. oxytoca, S. aureus, and A. flavus. The results clearly show that relatively good antimicrobial activities were obtained by the powdered cuttlebone against $K$. oxytoca and $A$. flavus (Tables 1 and 2 and Figures 4 and 5). Nevertheless, at the same time, no antibacterial activity was observed against $S$. aureus. In the present research, the maximum inhibition zones were observed against $K$. oxytoca (24 $\mathrm{mm}$ ) and A. flavus (23 mm), which illustrate and support the antimicrobial activities of powdered cuttlebone.

The findings of the present study showed the antimicrobial activities of powdered cuttlebone that it could be due to the presence of some polysaccharides such as chitosan and inorganic materials such as $\mathrm{CaCO}_{3}$ in the chemical structure of cuttlebone. Also, the results of previous studies have shown the antimicrobial function of the polysaccharides extracted from cuttlebone. In a study by Liu et al. (2006), the chitosan isolated from Sepioteuthis lessoniana showed an antibacterial activity against S. aureus, K. pneumonia, and V. cholerae (32). Shanmugam et al investigated the antibacterial activity of chitosan and phosphorylated chitosan extracted from the cuttlebone of Sepia kobiensis against some human pathogens (33). Similarly, Vairamani et al investigated the antibacterial activity of Sepiella inermis cuttlebone against human pathogens (34). Ramasamy et al evaluated antimicrobial potential of the polysaccharide extracted from cuttlebone and the methanolic extract extracted from the tissues of Sepia prashadi Winkworth against human pathogenic bacteria and fungi and reported the antimicrobial activities of $S$. prashadi Winkworth (35). Also, the antifungal activity of Sepia aculeata and Sepia brevimana cuttlebones was reported against some fungal strains (36).

Chitosan is a polymeric macromolecule which is not capable to pass the bacteria outer membrane. Therefore, it does not have a direct access to the cell intracellular sections. Nevertheless, chitosan due to the amino group in C-2 position, which has a positive charge in its structure, can interact with the anionic components (lipopolysaccharides and proteins) of the bacterial surface. Nevertheless, it shows that the chitosan biological activity depends on the chitosan $\mathrm{pH}$ solution, the target microorganism, and physico-chemical properties of chitosan. In addition, chitosan is a water-soluble derivative that could increase the permeability of bacterial cell membrane, which leads to the bacterial death by releasing cellular contents. Also, chitosan can precipitate on the microbial cell surface. Then, it makes an impervious layer

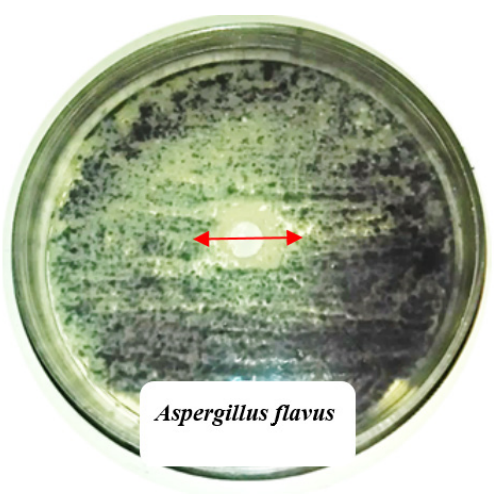

Figure 5. Cuttlebone antifungal activity against Aspergillus flavus. 
around the cell and blocks the channels, thereby, prevent from the transportation of essential nutrition into the bacterial cell, which leading to cell death (37-42).

$\mathrm{CaCO}_{3}$ is an inorganic material which forms the main part of cuttlebone structure. This compound with different concentrations is able to inhibit the growth of some bacteria and fungi species. The $\mathrm{CaCO}_{3}$ can prevents of bacteria cell wall formation. Failure of the cell wall synthesis process leads to cell death due to lysis. Also, when the membrane cell contact with the material, the bacterial metabolism is disrupted (43).

Therefore, the presence of chitosan and $\mathrm{CaCO}_{3}$ was the possible reason for the antimicrobial activities of powdered cuttlebone against $K$. oxytoca and A. flavus. Also, it seems that chitosan and $\mathrm{CaCO}_{3}$ which exist in the powdered form of cuttlebone, could not penetrate to the peptidoglycan cell wall of $S$. aureus and destroyed it. Perhaps, it could be due to the type of the bacterial cell wall or cuttlebone concentrations. The noteworthy point in the mentioned studies is that the antimicrobial activities are strongly dependent on the type of target microorganism, which is consistent with the results of the present study.

For comparative testing of novel drugs, MIC estimation is extensively used. It is applied to establish the organisms' susceptibility in the clinical laboratories (36). In the present study, MIC value for the powdered cuttlebone against both $K$. oxytoca and A. flavus was reported as $10^{-1}$ $\mathrm{mg} / \mathrm{mL}$, which indicates the best cuttlebone concentration that has strong antimicrobial activities.

Recently, the bioactivity study of natural products such as marine microorganisms due to their pharmacological application potential has received considerable attention. The initial efforts to study the antimicrobial activity in marine organisms were made around 1950s (33). Antibacterial activity has formerly been evaluated in the widespread range in the molluscan species such as oyster, mussel sea hare, etc. The searching principium for drugs from the marine environment is that marine animals and plants have a constant competition for reproduction, space, predation, etc $(44,45)$. Although, most of the agents isolated from the marine sources, shows antimicrobial activities but they were not strong enough to compete with all classical antimicrobials obtained from the other microorganisms. The larger part of marine organisms has not been investigated to identify effective antibiotics yet. But many researchers investigated the antibacterial activity of the extracted materials from the body tissue of marine animals $(46,47)$.

Different studies have shown the frequency of scrutable antimicrobial activity in marine molluscs. So, according to the mentioned results, it can be concluded that cephalopods are a source in the discovery of new substances to the development of drugs especially new types of antibiotics which have a better efficiency than the synthetic antibiotics (46-50). Generally, there are a few studies on the antimicrobial activities of internal bone of cephalopods.

The conspicuous point in the mentioned studies is that the cuttlebone biological activity is significantly dependent on the target microorganism species, cuttlebone structure, and its concentration. In the present study, the activity was also dependent on the cuttlebone concentration and type of microorganisms, which is consistent with the results of previous studies.

\section{Conclusion}

In different studies with various methods, the high frequency of detectable antimicrobial activities in the marine molluscs was reported. In the present study, the powdered cuttlebone showed antibacterial and antifungal activities against $K$. oxytoca and A. flavus, respectively. Additionally, the present study showed that the cuttlebone in the powdered form, which is thrown out as waste in the industries, is a very good and encouraging accessible natural antimicrobial source. Therefore, it is concluded that cuttlebones can be considered as a natural source of new substances to provide novel, low-cost, and safe antimicrobial agents.

\section{Acknowledgments}

The authors would like to thank the Environmental Health Engineering Research Center of Kerman University of Medical Sciences for their financial support.

\section{Ethical issues}

This study was approved by the Ethics and Research Committee of Kerman University of Medical Sciences (No: 95000481, Ethical code: IR.KMU.REC.1395.635). The authors certify that all data collected during the study are as stated in the manuscript, and no data from the study has been or will be published elsewhere separately.

\section{Competing interests}

The authors declare that they have no conflict of interests.

\section{Authors' contributions}

All authors were equally involved in the collection, analysis, and interpretation of the data. All authors critically reviewed, refined, and approved the manuscript.

\section{References}

1. Gong S, Fei P, Sun Q, Guo L, Jiang L, Duo K, et al. Action mode of cranberry anthocyanin on physiological and morphological properties of Staphylococcus aureus and its application in cooked meat. Food Microbiol 2021; 94: 103632. doi: 10.1016/j.fm.2020.103632.

2. In S, Khunnonkwao P, Wong N, Phosiran C, Jantama SS, Jantama K. Combining metabolic engineering and evolutionary adaptation in Klebsiella oxytoca KMS004 to significantly improve optically pure D-(-)-lactic acid yield and specific productivity in low nutrient medium. Appl Microbiol Biotechnol 2020; 104(22): 9565-79. doi: 10.1007/ s00253-020-10933-0. 
3. Duong TM, Nguyen PT, Le TV, Nguyen HL, Nguyen BN, Nguyen BP, et al. Drug-resistant Aspergillus flavus is highly prevalent in the environment of Vietnam: a new challenge for the management of aspergillosis? J Fungi (Basel) 2020; 6(4):296. doi: 10.3390/jof6040296.

4. Alves E, Dias M, Lopes D, Almeida A, Domingues MDR, Rey F. Antimicrobial lipids from plants and marine organisms: an overview of the current state-of-the-art and future prospects. Antibiotics (Basel) 2020; 9(8):441. doi: 10.3390/antibiotics9080441.

5. Tiralongo F, Messina G, Lombardo BM, Longhitano L, Li Volti G, Tibullo D. Skin mucus of marine fish as a source for the development of antimicrobial agents. Front Mar Sci 2020; 7: 541853. doi: 10.3389/fmars.2020.541853.

6. Balta I, Stef L, Pet I, Ward P, Callaway T, Ricke SC, et al. Antiviral activity of a novel mixture of natural antimicrobials, in vitro, and in a chicken infection model in vivo. Sci Rep 2020; 10(1): 16631. doi: 10.1038/s41598020-73916-1.

7. Mane MB, Bhandari VM, Balapure K, Ranade VV. Destroying antimicrobial resistant bacteria (AMR) and difficult, opportunistic pathogen using cavitation and natural oils/plant extract. Ultrason Sonochem 2020; 69: 105272. doi: 10.1016/j.ultsonch.2020.105272.

8. Abdullahi A, Khairulmazmi A, Yasmeen S, Ismail IS, Norhayu A, Sulaiman MR, et al. Phytochemical profiling and antimicrobial activity of ginger (Zingiber officinale) essential oils against important phytopathogens. Arab J Chem 2020; 13(11): 8012-25. doi: 10.1016/j.arabjc.2020.09.031.

9. Bao HN, Hien PT, Le Quyen V. Antioxidant and antimicrobial activities of hydrophilic extracts from shallot and garlic bulbs, and their effects on round scad during ICED storage. The Annals of the University Dunarea de Jos of Galati Fascicle VI-Food Technology 2020; 44(1): 26-44. doi: 10.35219/foodtechnology.2020.1.02.

10. Álvarez-Martínez FJ, Barrajón-Catalán E, Micol V. Tackling antibiotic resistance with compounds of natural origin: a comprehensive review. Biomedicines 2020; 8(10):405. doi: 10.3390/biomedicines8100405.

11. Schröder V, Rău I, Dobrin N, Stefanov C, Mihali CV, Pădurețu CC, et al. Micromorphological details and identification of chitinous wall structures in Rapana venosa (Gastropoda, Mollusca) egg capsules. Sci Rep 2020; 10(1): 14550. doi: 10.1038/s41598-020-71348-5.

12. Otjacques E, Repolho T, Paula JR, Simão S, Baptista M, Rosa R. Cuttlefish Buoyancy in response to food availability and ocean acidification. Biology (Basel) 2020; 9(7):147. doi: 10.3390/biology9070147.

13. Palaveniene A, Songailiene K, Baniukaitiene O, Tamburaci S, Kimna C, Tihminlioğlu F, et al. The effect of biomimetic coating and cuttlebone microparticle reinforcement on the osteoconductive properties of cellulose-based scaffolds. Int J Biol Macromol 2020; 152: 1194-204. doi: 10.1016/j. ijbiomac.2019.10.213.

14. Jiang M, Peng R, Han Q, Jiang X. Effects of temperature on the growth and microstructure formation of cuttlebone from cuttlefish Sepia pharaonis. Molluscan Res 2020; 40(2): 112-9. doi: 10.1080/13235818.2020.1718830.

15. Kangkan S, Arpornmaeklong P, Ummartyotin S. Synthesis of hydroxyapatite from cuttlebone under various $\mathrm{pH}$ conditions: an approach for medical materials. J Met Mater Miner 2020; 30(2): 136-41.

16. Venkatesan J, Rekha PD, Anil S, Bhatnagar I, Sudha PN,
Dechsakulwatana C, et al. Hydroxyapatite from cuttlefish bone: isolation, characterizations, and applications. Biotechnol Bioprocess Eng 2018; 23(4): 383-93. doi: 10.1007/s12257-018-0169-9.

17. Macha IJ, Ben-Nissan B. Marine skeletons: towards hard tissue repair and regeneration. Mar Drugs 2018; 16(7):225. doi: $10.3390 / \mathrm{md} 16070225$.

18. Mostoufi A, Bavarsad N, Aryanfar S, Akhgari A. New natural marine antacid drug from cuttlebone. Pharm Sci 2018; 24(3): 227-34. doi: 10.15171/ps.2018.33.

19. Xu J, Cao R, Li M, Chen G, Tian J. Superhydrophobic and superoleophilic cuttlebone with an inherent lamellar structure for continuous and effective oil spill cleanup. Chem Eng J 2020: 127596. doi: 10.1016/j.cej.2020.127596.

20. Qiu L, Yao L, Fang Y, Wang L, Xue M, Lin Z, et al. Effect of cuttlebone on healing of indomethacin-induced acute gastric mucosal lesions in rats. Evid Based Complement Alternat Med 2020; 2020: 9592608. doi: 10.1155/2020/9592608.

21. Tomano N, Prokaew A, Boonyuen S, Ummartyotin S. Development of Sr/Cao catalyst derived from cuttlebone (Sepia officinalis) for biodiesel production. J Met Mater Miner 2020; 30(1): 40-7.

22. Momeni S, Ahmadi R, Nabipour I. Arsenate removal from aqueous solutions by cuttlebone/copper oxide nanobiocomposite. Environ Sci Pollut Res Int 2019; 26(36): 37162-73. doi: 10.1007/s11356-019-06679-6.

23. Mourak A, Hajjaji M, Alagui A. Cured cuttlebone/chitosanheated clay composites: microstructural characterization and practical performances. J Build Eng 2019; 26: 100872. doi: 10.1016/j.jobe.2019.100872.

24. Palaveniene A, Harkavenko V, Kharchenko V, Daugela P, Pranskunas M, Juodzbalys G, et al. Cuttlebone as a marinederived material for preparing bone grafts. Mar Biotechnol (NY) 2018; 20(3): 363-74. doi: 10.1007/s10126-018-9816-6.

25. Vibhatabandhu P, Srithongouthai S. Biosorption of $\mathrm{Cr}(\mathrm{III})$ and $\mathrm{Ni}(\mathrm{II})$ from an aqueous solution using cuttlebone and application for battery manufacturing wastewater treatment. EnvironmentAsia 2018; 11(1): 1-14. doi: 10.14456/ea.2018.1.

26. Mansouri K, Fattahian H, Mansouri N, Mostafavi PG, Kajbafzadeh A. The role of cuttlebone and cuttlebone derived hydroxyapatite with platelet rich plasma on tibial bone defect healing in rabbit: an experimental study. Kafkas Univ Vet Fak Derg 2018; 24(1): 107-15. doi: 10.9775/ kvfd.2017.18444.

27. Dobaradaran S, Nabipour I, Keshtkar M, Faraji Ghasemi F, Nazarialamdarloo T, Khalifeh F, et al. Self-purification of marine environments for heavy metals: a study on removal of lead(II) and copper(II) by cuttlebone. Water Sci Technol 2017; 75(2): 474-81. doi: 10.2166/wst.2016.533.

28. Heng B, Qing W, Tao L, Li-ding Y, Xiao Y, Hong-run P, et al. Feasibility of cuttlebone/platelet-rich plasma compound in the repair of rabbit's cartilage injuries. Chinese J Tissue Eng Res 2015; 19(3): 352-7. doi: 10.3969/j.issn.20954344.2015.03.005.

29. Ramasamy P, Subhapradha N, Shanmugam V, Shanmugam A. Extraction, characterization and antioxidant property of chitosan from cuttlebone Sepia kobiensis (Hoyle 1885). Int J Biol Macromol 2014; 64: 202-12. doi: 10.1016/j. ijbiomac.2013.12.008.

30. Lee KM, Shim H, Lee GS, Park IH, Lee OS, Lim SC, et al. Chitin from the extract of cuttlebone induces acute inflammation and enhances MMP1 expression. 
Biomol Ther (Seoul) 2013; 21(3): 246-50. doi: 10.4062/ biomolther.2013.036.

31. Balouiri M, Sadiki M, Ibnsouda SK. Methods for in vitro evaluating antimicrobial activity: a review. J Pharm Anal 2016; 6(2): 71-9. doi: 10.1016/j.jpha.2015.11.005.

32. Liu N, Chen XG, Park HJ, Liu CG, Liu CS, Meng XH, et al. Effect of MW and concentration of chitosan on antibacterial activity of Escherichia coli. Carbohydr Polym 2006; 64(1): 60-5. doi: 10.1016/j.carbpol.2005.10.028.

33. Shanmugam A, Kathiresan K, Nayak L. Preparation, characterization and antibacterial activity of chitosan and phosphorylated chitosan from cuttlebone of Sepia kobiensis (Hoyle, 1885). Biotechnol Rep (Amst) 2015; 9: 25-30. doi: 10.1016/j.btre.2015.10.007.

34. Vairamani S, Subhapradha N, Ramasamy P, Barwin Vino A, Raveendran S, Shanmugam A. Antibacterial activity of methanolic extract of whole body tissue and ethylene diamine tetra acetate extract of cuttlebone of Sepiella inermis (Orbigny, 1848). Res J Microbiol 2012; 7(5): 26372. doi: 10.3923/jm.2012.263.272.

35. Ramasamy P, Barwin Vino A, Saravanan R, Subhapradha N, Shanmugam V, Shanmugam A. Screening of antimicrobial potential of polysaccharide from cuttlebone and methanolic extract from body tissue of Sepia prashadi Winkworth, 1936. Asian Pac J Trop Biomed 2011; 1(Suppl 2): S244-8. doi: 10.1016/s2221-1691(11)60163-9.

36. Shanmugam A, Mahalakshmi TS, Barwin Vino A. Antimicrobial activity of polysaccharides isolated from the cuttlebone of Sepia aculeata (Orbingy, 1848) and Sepia brevimana (Steenstrup, 1875): an approach to selected antimicrobial activity for human pathogenic microorganisms. J Fish Aquat Sci 2008; 3(5): 268-74. doi: 10.3923/jfas.2008.268.274

37. Huang X, You Z, Luo Y, Yang C, Ren J, Liu Y, et al. Antifungal activity of chitosan against Phytophthora infestans, the pathogen of potato late blight. Int J Biol Macromol 2021; 166: 1365-76. doi: 10.1016/j.ijbiomac.2020.11.016.

38. Akhtar MA, Mariotti CE, Conti B, Boccaccini AR. Electrophoretic deposition of ferulic acid loaded bioactive glass/chitosan as antibacterial and bioactive composite coatings. Surf Coat Technol 2021; 405: 126657. doi: 10.1016/j.surfcoat.2020.126657.

39. Ashraf MA, Li C, Zhang D, Zhao L, Fakhri A. Fabrication of silver phosphate-ilmenite nanocomposites supported on glycol chitosan for visible light-driven degradation, and antimicrobial activities. Int J Biol Macromol 2021; 169: 43642. doi: 10.1016/j.ijbiomac.2020.12.049.

40. Mittal A, Singh A, Benjakul S, Prodpran T, Nilsuwan K, Huda N, et al. Composite films based on chitosan and epigallocatechin gallate grafted chitosan: characterization, antioxidant and antimicrobial activities. Food Hydrocoll
2021; 111: 106384. doi: 10.1016/j.foodhyd.2020.106384.

41. Mei L, Jiang F, Zhang F, Zhang J, Li Y, Liu Y, et al. Alkynyl silver modified chitosan and its potential applications in food area. Carbohydr Polym 2021; 254: 117416. doi: 10.1016/j.carbpol.2020.117416.

42. Zhang X, Li Y, Guo M, Jin TZ, Arabi SA, He Q, et al. Antimicrobial and UV blocking properties of composite chitosan films with curcumin grafted cellulose nanofiber. Food Hydrocoll 2021; 112: 106337. doi: 10.1016/j. foodhyd.2020.106337.

43. Santos NC, Scodro RB, Sampiron EG, Ieque AL, Carvalho HC, Santos TD, et al. Minimum bactericidal concentration techniques in Mycobacterium tuberculosis: a systematic review. Microb Drug Resist 2020; 26(7): 752-65. doi: 10.1089/mdr.2019.0191.

44. Defer D, Bourgougnon N, Fleury Y. Screening for antibacterial and antiviral activities in three bivalve and two gastropod marine molluscs. Aquaculture 2009; 293(12): 1-7. doi: 10.1016/j.aquaculture.2009.03.047.

45. Malakootian M, Smith A Jr, Amiri Gharaghani M, Mahdizadeh H, Nasiri A, Yazdanpanah G. Decoloration of textile Acid Red 18 dye by hybrid UV/COP advanced oxidation process using $\mathrm{ZnO}$ as a catalyst immobilized on a stone surface. Desalin Water Treat 2020; 182: 385-94. doi: 10.5004/dwt.2020.25216.

46. Ramachandiran S, Satpaty S, Shankar K, Kalimuthu K, Muthuvel A. Anti-cancer properties of protein hydrolysate from the posterior salivary gland of Amphioctopus membranaceus (Quoy \& Gaimard, 1832). Int J Pept Res Ther 2020; 26(3): 1429-36. doi: 10.1007/s10989-019-099487.

47. Martínez-Morcillo S, Rodríguez-Gil JL, Fernández-Rubio J, Rodríguez-Mozaz S, Míguez-Santiyán MP, Valdes ME, et al. Presence of pharmaceutical compounds, levels of biochemical biomarkers in seafood tissues and risk assessment for human health: results from a case study in North-Western Spain. Int J Hyg Environ Health 2020; 223(1): 10-21. doi: 10.1016/j.ijheh.2019.10.011.

48. Zhukova NV. Fatty acids of marine mollusks: impact of diet, bacterial symbiosis and biosynthetic potential. Biomolecules 2019; 9(12):857. doi: 10.3390/biom9120857.

49. López Y, Cepas V, Soto SM. The marine ecosystem as a source of antibiotics. In: Rampelotto $\mathrm{PH}$, Trincone A. Grand Challenges in Marine Biotechnology. Cham: Springer; 2018. p. 3-48. doi: 10.1007/978-3-319-69075-9_1.

50. Jannah Z, Mubarok H, Syamsiyah F, Putri AA, Rohmawati L. Preparation of calcium carbonate (from shellfish)/ magnesium oxide composites as an antibacterial agent. IOP Conf Ser Mater Sci Eng 2018; 367: 012005. doi: 10.1088/1757-899x/367/1/012005. 